\title{
Nuclei of the Geniculate Bodies in the European Beaver
}

\author{
Stanisław SZTEYN \& Danuta GALERT
}

Szleyn S. \& Galert D., 1979: Nuclei of the geniculate bodies in the European beaver. Acta theriol., 24, 10: 109-114 [With Plate I]

The studies were made on the brain of 3 beavers (Castor fiber Linnaeus, 1758) aged from 6 to 18 months, sectioned to $15 \mu$. The sections were stained by the Nissl and Klüver Barrery methods. The paper contains a description of the situation and cytostructure of the nuclei of geniculate bodies in the beaver: nucleus corporis geniculati lateralis pars dorsalis, nucleus corporis geniculati lateralis pars ventralis and nucleus corporis geniculati medialis. A characteristic feature of the nuclei of these bodies in the beaver is the marked development of nucleus corporis geniculati lateralis and the weak formation and simple cell structure of nucleus corporis geniculati lateralis pars dorsalis.

|Teachers Training Coll., Dept. Biol., Żołnierska 14, 10-561 Olsztyn].

\section{INTRODUCTION}

Despite the fairly numerous studies on the optic and auditory centres and tracts in the central nervous system, many problems connected with these matters still remain open to discussion. Amongst such problems awaiting solution is that of the role played by the ventral part of the lateral geniculate body in optic conduction, the connection between the structure of the dorsal part of the lateral geniculate body and vision during the day and at night and the influence of mono- and binocular type of vision on formation of the dorsal and ventral parts of the lateral geniculate body. It would thus appear interesting to examine the structure of these nerve centres in the beaver, which leads a characteristic terrestial-aquatic way of life, its activity being far greater at night than during the day.

\section{MATERIALS AND METHODS}

Studies were made of the diencephalon of three beavens aged from 6-18 months. The material was fixed in neutralized formalin, dehydrated in an ethyl alcohol sequence, irradiated in turpentine and xylene and next embedded in paraffin and sectioned to $15 \mu$. Every other section was taken for examination. The sections were stained alternately in Löffler's methylene blue after Nissl's method and with cresyl violet and luxol fast blue after Klüver-Barrery's method. 


\section{RESULTS}

\section{Nucleus corporis geniculati lateralis}

From the aspect of cell structure and position two parts can be distinguished in the nucleus of the lateral geniculate body: the dorsal and ventral parts which, on account of very significant differences, must be described separately.

Nucleus corporis geniculati lateralis pars dorsalis (Figs. 1 and 3, gld) is a long, homogeneous band of cells clearly separated from its surroundings, situated near the dorso-lateral margin of the diencephalon. The posterior pole of gld appears at the level of a transverse plane running at a slight distance to the rear from the anterior margin of commisura habenularum. The anterior pole of gld disappears at a slight distance forwards from the posterior pole of nucleus reticularis dorsalis thalami. The average length of gld in the animals examined was $3.6 \mathrm{~mm}$.

In cross-sections the posterior part of gld is a narrow band of cells lying parallel to the dorsolateral margin of the diencephalon, above the ventral part of nucleus corporis geniculati lateralis pars ventralis. In a forward direction the cross section of the nucleus rapidly enlarges, gld cells fill the dorsolateral region of thalamus and cause a distinct prominence on its surface. In the middle part gld cells extentend downwards and the nucleus described contacts the ventral part of nucleus corporis geniculati lateralis. The boundary between the two nuclei is, however, still clearly visible owing to the considerable difference in the cell structure of both centres. In the anterior part gld again runs in a narrow elongated cell band.

The ventral part of the lateral geniculate body disappears earlier and gld again becomes an independent cell band. The number of cells forming gld gradually decreases while the prominence on the surface of the thalamus slowly becomes smaller and the nucleus gently disappears.

Gld is formed of dense but irregularly situated intensively staining multipolar cells, measuring from 20 to $35 \mu$ and less numerous spindleshaped cells measuring from 25 to $40 \mu$ along the long axis. Single rounded cells also appear sporadically in the nucleus. Gld cells contain numerous thick grains of tigroid matter. In the cross-section of the nucleus, poles with considerable density of cells, segregated by zones in which cells are very loosely distributed, are clearly visible.

Nucleus corporis geniculati lateralis pars ventralis (Fig. 1 and $4, g l v$ ) is a far more weakly formed and less distinct cell band than gld. Glv is shifted very slightly backwards in relation to gld - the anterior and posterior poles of $g l v$ lie at about $0.8 \mathrm{~mm}$ to the rear in relation to the 
analogical poles of gld. Length of $g l v$ in the animals examined was on an average $3.6 \mathrm{~mm}$.

In cross-sections the posterior part of $g l v$ is a small narrow group of cells which adheres to the lateral surface of the diencephalon on the dorsolateral side of zona incerta. Gld appears slightly to the fore from the posterior pole of $g l v$ above the nucleus described. The two nuclei at first lie at a considerable distance from each other. At the level of $1 / 3$ of the posterior part the dorsal surface of glv contacts the ventral surface of the rapidly enlarging gld. In the middle part cross-sections show that $g l v$ has a triangular shape, the upper part of which adheres to $g l d$, and lateral side to the surface of the diencephalon. The crosssection of the nucleus is largest in this part, but even so much smaller than the cross-section of gld. In the anterior part the cross-section of this nucleus hardly decreases in "size at all, but the number of cells forming $g l v$ gradually decreases, they are increasingly loosely arranged and gradually disappear at a distance of about $0.8 \mathrm{~mm}$ from the anterior pole of gld.

Glv is formed of fairly loose and irregularly distributed multipolar cells measuring from 15 to $25 \mu$ and spindle-shaped cells measuring from 15 to $30 \mu$ along the long axis. The cells of glv contain a small number of thick grains of tigroid matter and stain less intensely than gld cells. The large number of glial cells situated between glv cells give this centre a compact form.

\section{Nucleus corporis geniculati medialis}

Nucleus corporis geniculati medialis (Figs. 2 and $5, \mathrm{gm}$ ) is a large homogeneous band of cells situated in the posterior part of the diencephalon near its lateral surface. The posterior pole of $\mathrm{gm}$ appears at a small distance to the rear of a transverse plane running through the anterior pole of nucleus motorius nervi trigemini. The anterior pole of this nucleus does not reach the transverse plane running through the posterior pole of $g l v$, the interval between the two nuclei being about $0.4 \mathrm{~mm}$.

In cross-sections the posterior pole of $\mathrm{gm}$ appears as a small group of cells situated near the lateral wall of the diencephalon. In a forward direction $g m$ very rapidly increases in size and forms a distinct prominence in the lateral wall of the diencephalon. The cells of $\mathrm{gm}$ completely fill this prominence. The nucleus takes the form of a broad oval. On the medial side $g m$ is adjacent in this part to nucleus suprageniculatus from which it is, however, distinctly separated by a cell-less zone. As from the level of the posterior boundary of $1 / 5$ of the anterior part, the cross section of $g m$ abruptly decreases in size, takes 
the form of a rounded group of cells which gradually departs from the lateral surface of the diencephalon and disappears fairly quickly.

$\mathrm{Gm}$ is formed of multipolar cells, measuring from $20-45 \mu$ and distributed fairly densely but irregularly. The cells of $\mathrm{gm}$ contain a small number of coarse grains of tigroid matter and do not stain intensely. A narrow zone of more deeply staining cells can be distinguished near the dorsal margin. In addition to multipolar cells there is also a small number of spindle-shaped cells, varying in dimensions from 20 to $30 \mu$ along the long axis, in this part of $\mathrm{gm}$. Multipolar cells do not exceed $30 \mu$ in this place.

\section{DISCUSSION}

The structure of nuclei of the geniculate bodies in the beaver exhibits many characteristic specific features which require detailed emhasis. Gld in the beaver is a homogeneous band of cells, not exhibiting division and possessing a simple cytostructure not differentiated into strata. This relatively primitive structure of gld in the beaver is very similar to the structure of the analogical nerve centre in the nutria (S z tey n, 1968), but differs distinctly from the formation of gld in predatory and ungulate animals. Gadamski et al. (1973) in the cow, Solnitzky (1963) in the wild boar, We lento $(1964,1966)$ in pigs and cows, Szteyn (1967) in sheep and Adrianov \& $\mathrm{M}$ ie ring (1959) in the dog found that gld was divided into a dorsal and ventral region, and described a distinctly visible stratified structure in the cellular structure of this nucleus. Wolla rd (1926) stated that complicated structure in the cell structure of gld depends on the degree of formation of macula lutea, while W a $11 \mathrm{~s}$ (1953) made this dependent on the ratio of decussated and undecussated fibres in the optic tract. It is however difficult to connect the cytostructure of gld with the ability to see during the day and at night. Such hypotheses were shown to be unsound by V aidy a (1963) who found no differences in the structure of gld in animals of either a decidedly nocturnal or diurnal way of life. The primitive structure of gld in the beaver gives grounds for assuming that the optic organ is only weakly formed in this animal.

Glv in the beaver differs greatly in respect of its location from the position of the analogical nucleus in ungulate mammals. In the latter animals the posterior part of glv lies on the lateral side of gld, or the whole of glv lies in front of gld (W elento, 1964, 1966; S z te y n, 1967; Solnitzky, 1963; Gadamski et al., 1973). The situation of glv below gld in the beaver is similar to the relations found in nutria ( $\mathrm{S} z$ t e y n, 1968), although this nucleus is far more strongly formed in 
the beaver than the $g l v$ of the nutria. Its length is equal to the length of gld, whereas in the nutria glv occurs only at the level of the medial part of gld. It must also be emphasised that A drianov \& Miering (1953) did not observe an accumulation of cells in the dog which would correspond to $g l v$ of other mammals. It would however be very risky to reach conclusions as to function on the basis of the structure of this nucleus, on account of the still hypothetic role of $g l v$ in the process of vision. It may however be mentioned that certain authors (e.g. Wollard, 1926) connect the strong development of glv with the monocular kind of vision.

When comparing the structure of $g m$ in the beaver with the structure of this nucleus in ungulate mammals it would appear that this nerve centre is relatively more strongly formed in the beaver. Further evidence of this is also provided by the cytostructural differentiation of $\mathrm{gm}$ in the beaver into macro- and microcellular parts. Division of this kind in cell structure among ungulates occurs only in the goat (W e l e $\mathrm{n}$ to, 1966). Division of $\mathrm{gm}$ into a macro- and microcellular part cannot be seen in the nutria also ( $\mathrm{s} z \mathrm{t}$ e y $\mathrm{n}, 1968$ ). It would therefore appear that the sense of hearing is strongly formed in the beaver and predominates over the sense of sight.

It must however be pointed out that in some predatory animals $g m$ is even more strongly formed and has a more complicated structure than in the beaver's gm, for instance S y chow a (1962) described six parts in the $g m$ of the dog on the basis of the fibrostructure.

\section{REFERENCES}

1. Adrianov O. \& Miering T., 1959: Atlas mozga sobaki. Gosud. izdat. mied. lit. Moskwa.

2 Gadamski R., Flieger S. \& Sławomirski J., 1973: Budowa jąder ciał kolankowanych u krowy. Annals Univ. M. Curie-Skłodowska, Sec. DD, 28: $47-54$.

3. Solnitzky O., 1963: The comparative anatomy of the lateral geniculate body. Anat. Rec., 145: 368-382.

4. Sychowa B., 1962: Medial geniculate body of the dog. J. comp. Neurol., 118: $355-364$.

5. Szteyn S. 1968: The nuclei of the geniculate body of the coypu. Pol. Arch. Wet., 11: $337-346$.

6. Szteyn S., 1967: Topography and structure of the geniculate bodies in sheep. Folia morphol., 26: 77-87.

7. W a 11 s G.L., 1953: The lateral geniculate nucleus and visual histophysiology. Univ, Calif. Press, Los Angeles.

8. We lento J., 1964: Budowa i topografia jąder międzymózgowia świni. Annals Univ. M. Curie-Skłodowska, Sec. DD, 19: 125-172.

9. Welento J., 1966: Jądra cial kolankowatych krowy. Folia morphol., 25: 587-596. 
10. Woola rd H.H., 1926: Notes on the retina and lateral geniculate-bodies in tupaia, tarsius, nicticebus and hapale. Brain, 49: $31-77$.

Accepted May 16. 1978.

Stanisław SZTEYN i Danuta GALERT

JĄDRA CIA£ KOLANKOWATYCH U BOBRA EUROPEJSKIEGO

Streszczenie

Badania zostały przeprowadzone na mózgowiach 3 bobrów (Castor fiber Linna e us, 1758) ciętych na skrawki poprzeczne grubości $15 \mu$. Skrawki barwiono na przemian metodami Nissla i Klüvera-Barrery. W pracy opisano topografię i budowę komórkową jąder ciał kolankowatych bobra. Jądro ciała kolankowatego bocznego bobra zbudowane jest z 2 części - grzbietowej i brzusznej (nucleus corporis geniculati lateralis pars dorsalis i pars ventralis). Jądro ciała kolankowatego bocznego (nucleus corporis geniculati medialis) jest tworem jednolitym. Cechą charakterystyczną jąder ciał kolankowatych bobra jest słabe wykształcenie i nieskomplikowana budowa komórkowa nucleus corporis geniculati lateralis pars dorsalis i silnie rozwinięte nucleus corporis geniculati medialis, co pozwala przypuszczać, że zmysł słuchu dominuje u tego zwienzęcia nad zmysłem wzroku.

\section{EXPLANATION OF PLATE}

Plate I

Fig. 1. Cross-section of beaver diencephalon at level of gld.

Fig. 2. Cross-section of beaver diencephalon at level of $\mathrm{gm}$.

Fig. 3. gld cells.

Fig. 4. glv cells.

Fig. 5. gm cells.

ca - cornu Ammonis,

gld - nucleus corporis geniculati lateralis pars dorsalis,

glv - nucleus corporis geniculati lateralis pars ventralis,

gm - nucleus corporis geniculati medialis,

$r v$ - nucleus reticularis ventralis,

$v$ III - ventriculus III. 


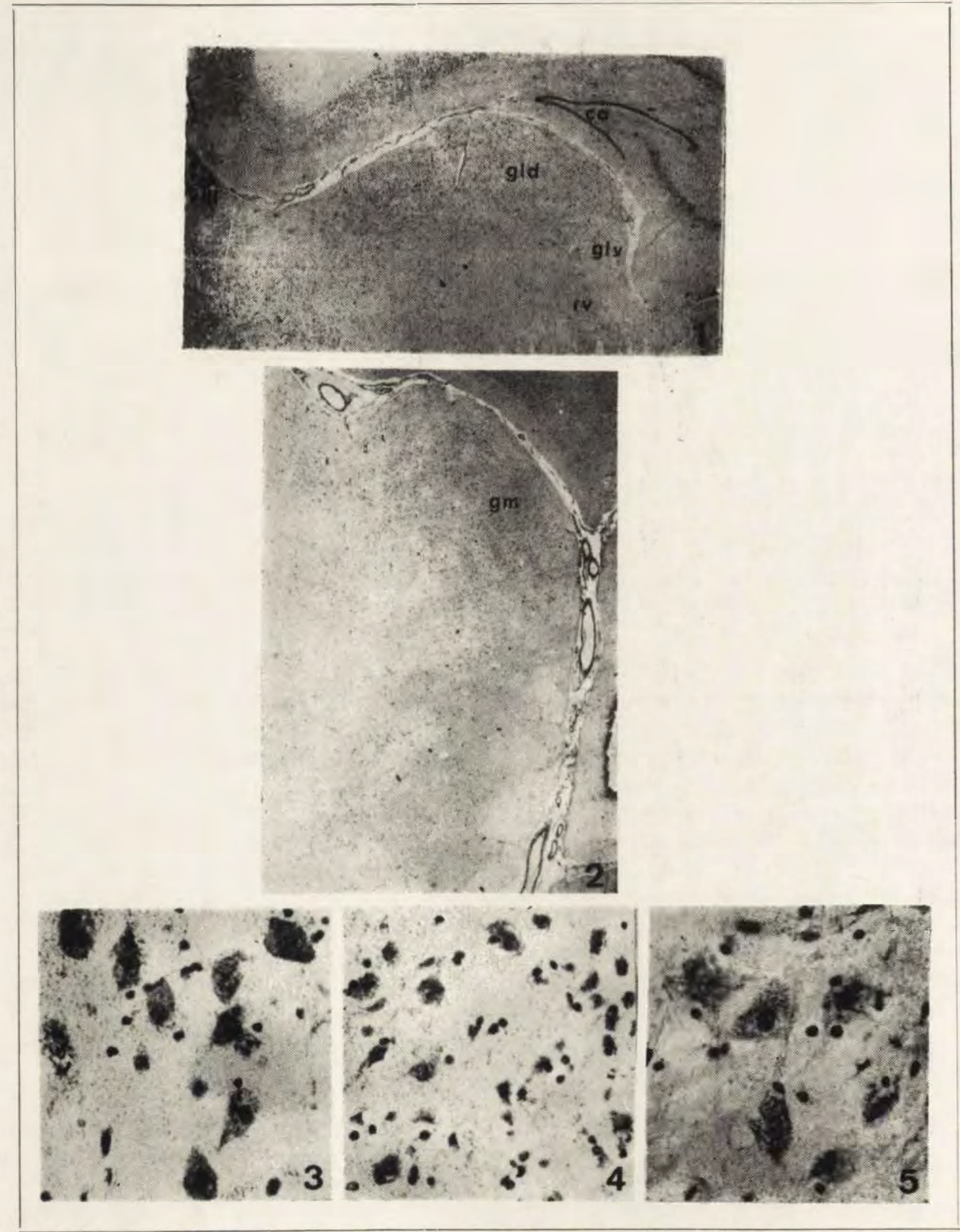

S. Szteyn \& D. Galert 